I $\begin{array}{lllll} & 8 & . & 5\end{array}$

\title{
Editor's Column: Farewell
}

LLOW ME TO BEGIN THIS COLUMN WITH A BIT OF EPISTO-
lary history and share with you a letter that I wrote over a year ago:

March 5, 2002

Phyllis Franklin

Executive Director

Modern Language Association

26 Broadway, 3rd Floor

New York, NY 10004-1789

Dear Phyllis:

I am in receipt of your letter in which you inform me that the Executive Council of the MLA has voted to extend my term as editor of PMLA. I am most gratified by this decision, inasmuch as it indicates the Executive Council's support of the work that the Editorial Board and I have been doing with the journal.

Nevertheless, after a great deal of thought and with a heavy heart, I have decided that I cannot accept your gracious invitation. My professional and personal commitments - being chair of a rather large department and father to two small children-make it impossible for me to maintain the level of involvement and commitment that, as you know, is required daily by a journal of $P M L A$ 's stature and complexity.

Furthermore, I also think that, given the speed at which our profession is changing, it makes a great deal of sense to have the editor change every three years to ensure that the journal receives a new infusion of energy and ideas as often as possible.

I have enjoyed tremendously the time that I have served as editor, and I will continue to strive to maintain the journal's high quality in the year and a half that remains in my current term. I end by

(C) 2003 By THE MODERN LANGUAge ASSOCIATION OF AMERICA 
thanking you profoundly for the trust in me that you and the council showed when you placed in my care this invaluable thing that is $P M L A$.

\section{Sincerely, Carlos J. Alonso Editor, PMLA}

This is, then, my final column as editor of $P M L A$. I feel a personal and overwhelming sense of gratefulness to a number of individuals associated with the journal, whose contribution to its production should be known by the entire readership. During the years I was editor, I worked closely with three Editorial Boards, each with its own personality but all composed of some of the smartest scholars I have ever met: Margaret Higonnet, Garrett Stewart, Frank Trommler, Jay Fliegelman, Mireille Rosello, Bruce Smith, Howard Bloch, Joseph Boone, Avital Ronell, Nancy Armstrong, Christie McDonald, and Patricia Yaeger. Listening to them explain their views on the submissions under consideration made me a better critic, and their decisions made PMLA an even better journal. Judy Goulding, managing editor of PMLA, displayed an unfailing professionalism and elegance that balanced perfectly my instinct to handle matters too efficiently. Her deep sense of justice and fair play is the reason PMLA has an ethical resonance among its readership. Eric Wirth, copyeditor nonpareil, taught me in his gentle way more about writing English prose than I have learned in many years of formal schooling on the subject. Angel Butts, Erin Farber, and Annabel Schneider are the editorial staff at the MLA whose close attention to the relentless, day-to-day work keeps the journal alive. Jennifer van Frank, my editorial assistant at Penn, rescued me many times from the heavy tolling of an impending deadline. My wife, Anne E. Lubell, who already juggles valiantly the impossible demands of both her profession as a lawyer and motherhood, bore with understanding the additional burdens imposed on me by the journal. And Miguel and Ari, my pre- cious, precious children, asked early on during my tenure as editor what PMLA was all about, in order-I suspect - to understand why I was not spending as much time with them as they were accustomed to. I gather that my answer was not entirely satisfactory, given that they still groan every time I let them know that I must spend yet another weekend at the office. To say that I owe just gratitude to these grown-ups and children alike would be most ungenerous.

Finally, I must thank you, the readers of PMLA, for submitting your work to the journal in increased numbers that have brought submissions to pre-1997 levels, thereby reversing the downward trend in submissions that, as I warned in my inaugural column as editor, threatened the journal's survival. For instance, the editorial office has received upward of 130 submissions for the special topic On Poetry, one of two such topics finalized during my editorship (the other, The History of the Book and the Idea of Literature, was first advertised in the May 2003 issue). Furthermore, a small but significant change in the process of considering submissions-sending each manuscript to two readers simultaneously rather than sequentially-has substantially reduced the amount of time that authors must wait for editorial decisions. Judging from several expressions of surprise and satisfaction I have received from authors commenting on the quick turnaround of their submissions, I believe it is only a matter of time before the general perception of the journal's evaluation process as long and cumbersome changes and authors consequently have a further inducement to submit their best work to PMLA.

There are ponderous yet exhilarating moments in life in which one is entrusted with something priceless for nurturing and safekeeping. In the case of PMLA, such a responsibility is made even more trying because success depends almost completely on the collaboration and good will of strangers. In that sense, editing a journal and raising children are similar undertakings: soon you realize that, to do your job well, you 
will have to depend on innumerable acts of generosity, kindness, and grace by others, especially acts you are not there to witness. In fact, no realization is more frightening to someone engaged in either endeavor. But perhaps that was the point - and the challenge-all along: to make the contributors to PMLA and its readers understand the investment they have-perhaps unbeknownst to them-in the journal's sustenance.

Being editor of PMLA is a grueling, taxing responsibility. Hardly a day went by during the three years of my tenure as editor in which I did not have to tend to business related to it: an e-mail message, a fax, a decline letter, preparation for meetings of the board, correspondence with authors, and so on. But in the end, I consider myself blessed for having endured all those strivings and exertions. For I was also a daily witness to some of the best traits of our profession. I refer not simply to the generally high quality of the submissions but also to the magnanimity of consultant readers who clearly spent hours writing reviews to improve the work of their peers, even while recommending that an essay be declined; to the dedication of members of the Editorial Board who worked to breathe life into manuscripts that the authors' missteps had compromised; to the sometimes heroic perseverence of authors who undertook to revise work that needed one more turn of the screw to rise from strong to excellent. The knowledge of such acts should remind us that, despite our worst moments and our sometimes abominable behavior toward one another, we are all in this together, that there is a collective dimension to what we do that transcends the selfishness and pettiness chronicled in anecdotes about our métier. In its desire to be the symbol and instrument of this community, PMLA represents the hopeful, ever-renewed possibility of channeling and being in touch with that powerful presence of the collective in our work. I like to assuage my fears as a parent by believing that my children, Miguel and Ari, will only find in their paths in life similar examples of decency and selflessness.

I walk away from this post without the expected sense of relief or even of accomplishment at the anticipated end of a long run. For me there will be no unburdening of responsibility but rather the opposite: the realization that I, as much as you-that we-must continue to share the responsibility of making PMLA thrive. For the editor's voice is simply the prosopopoeia, the personification, of this collective sense of care-of this feeling of abiding obligation toward the journal. For this reason, I have come to understand with a little dread and a great deal of affection why both nostalgia and relief are equally forbidden to me now: I have finally realized that, in a profound and compelling way, I will be "editor" of PMLA forever.

Carlos J. Alonso 